Article

\title{
Biodeterioration Patterns and Their Interpretation for Potential Applications to Stone Conservation: A Hypothesis from Allelopathic Inhibitory Effects of Lichens on the Caestia Pyramid (Rome)
}

\author{
Giulia Caneva ${ }^{1}$, Maria Rosaria Fidanza ${ }^{1, * \mathbb{D}}$, Chiara Tonon ${ }^{2}$ and Sergio Enrico Favero-Longo ${ }^{2}$ \\ 1 Department of Science, Roma Tre University, Viale Marconi 446, 00146 Roma, Italy; \\ giulia.caneva@uniroma3.it \\ 2 Department of Life Sciences and Systems Biology, University of Torino, Viale Mattioli 25, 10125 Torino, Italy; \\ chiara.tonon@unito.it (C.T.); sergio.favero@unito.it (S.E.F.-L.) \\ * Correspondence: mariarosaria.fidanza@uniroma3.it; Tel.: + 39-06-5733-6374
}

Received: 16 December 2019; Accepted: 27 January 2020; Published: 5 February 2020

\begin{abstract}
The colonisation of stone by different organisms often leaves biodeterioration patterns (BPs) on the surfaces even if their presence is no longer detectable. Peculiar weathering patterns on monuments and rocks, such as pitting phenomena, were recognised as a source of information on past colonisers and environmental conditions. The evident inhibition areas for new bio-patinas observed on the marble blocks of the Caestia Pyramid in Rome, recognisable as tracks of previous colonisations, seem a source for developing new natural products suitable for restoration activities. To hypothesise past occurring communities and species, which gave rise to such BPs, we carried out both in situ observations and analyses of the rich historical available iconography (mainly photographs). Moreover, we analysed literature on the lichen species colonising carbonate stones used in Roman sites. Considering morphology, biochemical properties and historical data on 90 lichen species already reported in Latium archaeological sites, we suppose lichen species belonging to the genus Circinaria (Aspicilia s.l.) to be the main aetiological agent of such peculiar BPs. These results seem relevant to highlight the long-lasting allelopathic properties of some lichen substances potentially applicable as a natural product to control colonisation, improving the environmental and economical sustainability of stone restoration.
\end{abstract}

Keywords: lichen allelopathic substances; natural biocides; stone biodeterioration; stone conservation; historical photographs

\section{Introduction}

Stone monuments are affected in different ways by organisms and microorganisms, whose metabolic activity and growth can impact them aesthetically, chemically and/or physically, determining biodeterioration phenomena [1-6]. Sometimes their colonisation can also exert a positive bioprotective action, as shown for some monuments all over the world [7-9]. In particular, despite the deteriogenic interactions, their covering can lower the weathering by external environmental factors (e.g., winds, low temperatures, rainfalls) when these are very aggressive $[9,10]$.

Lithobiontic communities originate specific biodeterioration patterns (BPs), forming patinas, encrustations, pits, cracks, discolorations and detachments, which change in relation to lighting conditions and humidity values, and correspond to specific weathering patterns [11,12]. Studies on the rocks of the Negev desert (Israel) showed differentiable weathering patterns, which were explained by the effects of different environmental exposures, and related to different BPs [13]. This information was used for 
interpreting BPs occurring in several archaeological areas in Israel and demonstrating the existence of different bioclimatic conditions before their burial, which stopped their growths but left their evident tracks $[14,15]$. In the case of the Trajan column (Rome), a diffuse pitting is still detectable on South-exposed marble surfaces, which had never shown any evidence of living organisms [16,17]. Such weathering patterns were interpreted as the consequence of past growths of endolithic communities of cyanobacteria and lichens, occurring in the areas wetted by incident rainfall [16]. The disappearance of such living communities, whose presence was recognisable in the historical photographs by typical blackening, was related to the building of the protective antibomb walls, during World War II, which caused a six-year period of darkness and the death of the photosynthesising microflora [16]. At present, the micro- and macroclimatic conditions of the area appear to be less suitable for the microflora in comparison to the past, and the chemical effects of dissolution are prevailing. Changes in biodeterioration phenomena on stone monuments in Rome were also related to the climatic changes between the 18th and 20th century, crossing evidence from past iconographic documentation and bioclimatic datasets [17-20]. Even if the communities are no longer living, due to the climatic changes that have occurred or peculiar environmental conditions in the past, the detected weathering patterns were useful in the understanding of past phenomena $[19,20]$, and they may also potentially provide information for the future conservation of stone materials.

Regarding lichen tracks, in particular, biodeterioration studies have shown the correlation between pitting phenomena and the past presence of endolithic species [21]. The occurrence of oxalate deposits was also often related to lichen-driven biomineralisation processes [22,23] even if other possible causes can occur. This was proven in the case of the Trajan Column, on which past organic protective treatments favoured fungal growths and chemical oxidation processes [24]. On the other hand, lichens are producers of diverse secondary metabolites (more than 1000), variously localised through the thallus layers depending on their ecophysiological role [25-27]. Many of them are recognised bioactive substances, having different types of properties: antimicrobial, antialgal, antifungal, larvicidal, and herbicidal [26,28]. Although their secretion has long been associated to an allelopathic function [29,30], and as a factor regulating the development of lichen communities [30-32], the effects of such processes on stone surfaces have been poorly characterised. Some secondary metabolites with acidic and chelating functions have been characterised as agents of mineral leaching [33,34], but no study has ever verified if their allelopathic activity in situ could explain the presence of some tracks of uncolonised surfaces, which are compatible with the shape and size of lichen thalli and continue to appear clean after years. This could support the hypothesis of the long-lasting allelopathic properties of these substances and their potential application as natural products to control colonisation and biodeterioration by other microorganisms, as cyanobacteria and black fungi, on stone monuments [35]. Such new products are welcomed to improve the environmental sustainability of products used in restoration, since traditional biocides are often unsafe and removed from the market because of their toxicity [36-38]. Moreover, their potential long-lasting effects may contribute to the economic sustainability of stone heritage conservation [37].

The Caestia Pyramid in Rome, which still shows different evidence of previous colonisations, including lichens [17], and peculiar inhibition areas, is an interesting site to test such a hypothesis. Moreover, the rich historical iconography (paintings, photographs) available for the site and in situ observations carried out in recent decades give proof of the rich biological colonisation which occurred in the past, as well as of the rural context of the surrounding areas along the centuries (Figure 1). 


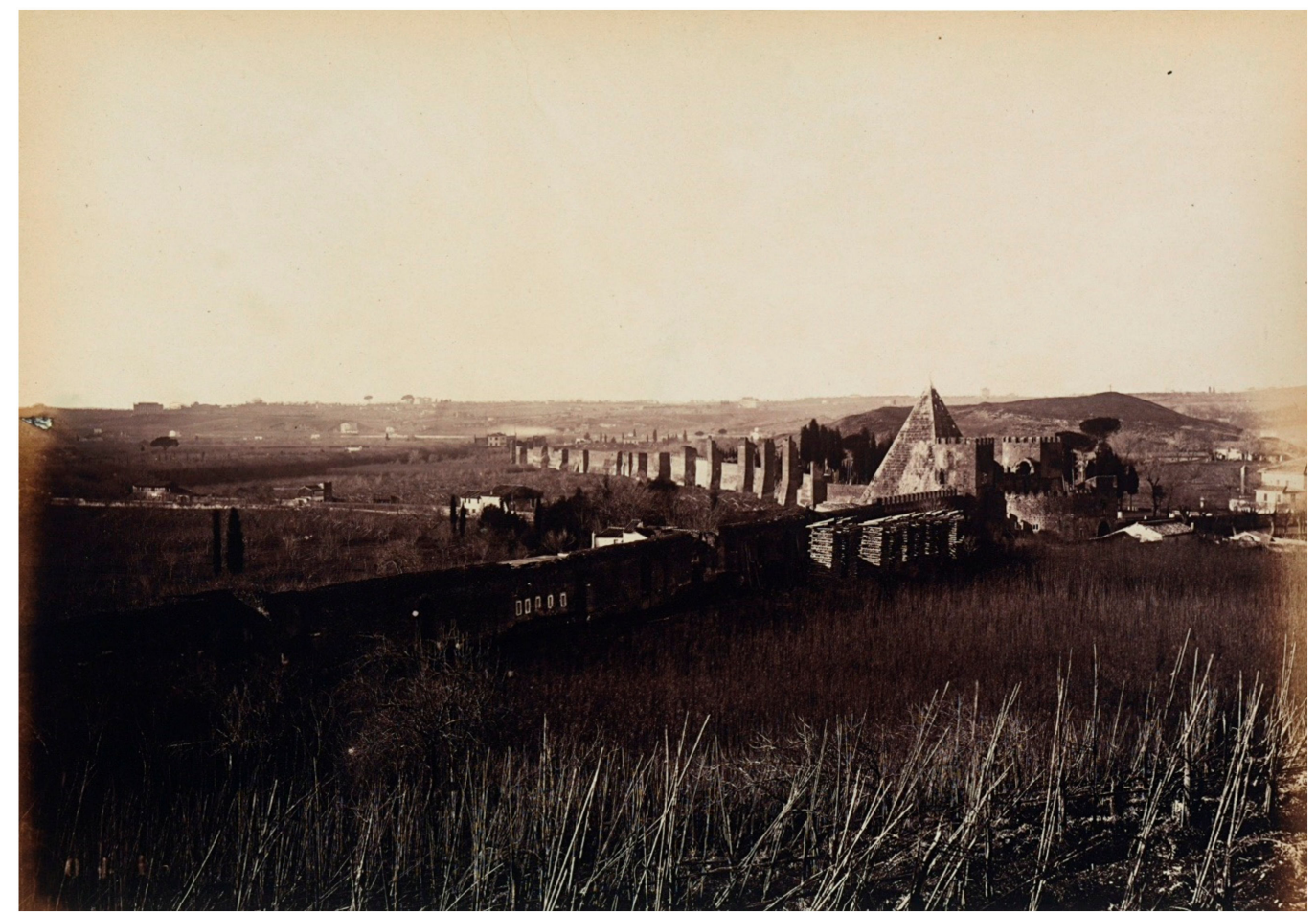

Figure 1. Photographic view of the Caestia Pyramid dated back to 1880-1890, when it was at the border of the built area of the city (Alinari Archives, Aurelian Walls, Rome, 1880-1890 ca., unknown author, LVQ-L-000308-0023).

The Pyramid is a large cemetery monument ( $36.40 \mathrm{~m}$ high, with a square base of $29.50 \mathrm{~m}$ ), built between 18 and 12 B.C. in honour of the rich politician and merchant Gaius Caestius, member of the religious corporation Epulonum collegium. The shape imitates the style of the Egyptian sepulchral buildings, as a sign of the recent extension of the political power of Rome [39]. It was built using stones and mortars, cladded with high-quality marble blocks extracted from the ancient quarry of Luni (between La Spezia and Carrara, Italy), which explains the name of "White" Pyramid. This famous Lunense marble is mineralogically dominated by calcite, with very small amounts of muscovite and dolomite-type carbonates [40]. The monument has been restored several times over the centuries, sometimes substituting the most weathered marble blocks with new ones, as in the case of the extensive and documented restoration which occurred in 1663 [41]. In that period, and over subsequent centuries, the biodeterioration phenomena were extensive, with a relevant growth of higher plants (Figure 1). Further investigations and restoration activities were carried out on the monument during the last few decades, and a survey of biodeterioration phenomena was made in the 1990s, showing the biological composition-due to cyanobacteria, fungi and lichens-of the diffuse dark patinas of the wall surfaces $[17,42]$. In more recent years, a survey was made before the last restoration (carried out in 2013-2014). The marble was colonised by many kinds of organisms, among which microorganisms forming a grey/black crust and including coccoid and filamentous cyanobacteria (genus Gloeocapsa, Chroococcus and Scytonema), and green algae (often lichenised on the surface of the marble), which also displayed endolithic penetration [43]. During the last restoration, diverse cleaning treatments were applied on such bio-patinas [44].

The aims of this paper are: (i) to give evidence of BPs on the Pyramid; (ii) to give a hypothesis on possible aetiological agent of the tracks of uncolonised surfaces; and (iii) to lay the basis for the selection of promising natural substances with long-lasting activity to be employed for stone conservation. 


\section{Materials and Methods}

\subsection{Evidence of the Diffuse Colonisation and BPs on the Pyramid During the Previous Centuries and} Lichen Tracks

Observations of the biological cover in different historical periods were conducted on photographic materials at a high resolution level, collected by several archives (Table 1) and dating back to the end of 19th century up to today. We analysed the morphology of the different BPs patterns recognisable on such documentation. Generally, a detailed taxonomic identification was not possible, but we carried out an interpretation of possible colonisers, at the level of main phyla and, sometimes, also genera, considering the direct observations performed on residual communities in the 1990s [17]. The visible morphological characters were also helpful in identifying microorganisms, as algae and cyanobacteria tend to develop dark patinas, easily detectable in black and white photographs when considering their distribution related to incident rainfall or water percolation $[11,19,20]$. On the other hand, lichens usually show the borders of the thalli as evident patches, and mosses have the shape of pulvines, as previously observed in other historical documents [19,20]. In particular, we supported the interpretation of the growth inhibition areas and the possible effects of past lichen presence with the observation of close photographs taken in the 1990s, which were only partially used in a previous paper related to biopitting phenomena [17]. We also carried out further observations in the 2000s, before the last biocide treatments carried out in 1993 and 2003 and then between 2013 and 2018.

Table 1. Sources of the photographic material.

\begin{tabular}{cc} 
Archive & Number of Records \\
\hline Archivi Alinari & 31 \\
Archivio Fotografico Giuseppe Primoli & 8 \\
Biblioteca Nazionale Centrale di Roma & 1 \\
Bibliothèque Nationale de France & 1 \\
degli Studi Roma Tre & 1 \\
CeDOT_Centro di Documentazione e Osservazione del Territorio dell'Università & 6 \\
CROMA-Centro per lo Studio di Roma dell'Università degli Studi Roma Tre & 13 \\
Deutsches Archäologisches Institut & 20 \\
ICCD-Istituto Centrale per il Catalogo e la Documentazione del Ministero per i \\
beni e le attività culturali e per il turismo
\end{tabular}

\subsection{Hypothesis on the Aetiological Agent of the Weathering Patterns and Selection of Promising} Bioactive Substances

In order to evaluate the lichen species which possibly occurred in the past on the marble blocks of the Caestia Pyramid, we used historical records on lichen colonisation on carbonate lithotypes in Latium archaeological sites surveyed in the 1980s [45]. We also checked older historical data of the 19th century $[46,47]$ on the occurrence of lichens on the Colosseum (Rome) even if they only partially dealt with carbonate substrates (mostly artificial stones, as mortars), because they could provide information on diversity and autoecological traits of the lichen flora in Rome in the past centuries.

We evaluated the potential correlation of lichen species recognised as possible colonisers of the Pyramid with the surfaces now noncolonised by cyanobacteria. In particular, the proposal of a taxonomical identification of lichens responsible for the inhibitory phenomenon was carried out considering the following factors: the morphological traits (growth form, thallus continuity and size), the production of secondary metabolites and autoecology of lichen species [48-50], their potential distribution in Rome, taking into account the different climatic conditions of the area in the last century [18,19], and the direct support by available photographic materials dating to the 1990s.

Given the typical secondary metabolites of the lichen species hypothesised by the previous elaborations [50,51], we derived the most probable compounds secreted on the surface. In a parallel 
work, we also spectroscopically tested the evidence of metabolite traces potentially responsible for the inhibitory activity of certain species, the occurrence of which we hypothesised [52].

Finally, the potentially promising bioactivity of such lichen compounds was derived by PubChem [53] and specialised literature.

\section{Results and Discussion}

\subsection{Evidence of the Past Colonisation and BPs on the Pyramid, Including Lichens and Their Tracks}

The analysis of the dataset of about one hundred documents testifies the diffuse colonisation of the Pyramid, with blackening already recognisable in the oldest photographic documentation of the 19th century until the first half of the 20th century. Even if, in polluted environments, blackening phenomena can arise from residues of fossil fuels combustion-as detected on the Caestia Pyramid [42] — most of the blackish patinas and crusts were of biological origin [17,43]. Indeed, black crusts due to pollution phenomena are often detected in those areas protected from the leaching effects of rainfall $[1,19,54]$. Oppositely, when the blackening is located on the blocks wetted by rainfall-as in the case of the Pyramid-it has a clear biological origin, because water tends to dissolve and remove pollutants, in parallel favouring the biological growth [17].

All the historical photographic images display the prolonged presence of various BPs, which decreased in the last few decades. The current decrease in rainfall and increase in xeric conditions in the city have already been highlighted in the literature $[55,56]$. These micro- and bioclimatic changes and the recent restoration activities explain the reduction of BPs in recent years. Here, we report the following past BPs, which are distinguishable on old photographic documentation, as exemplified in Figure 2:

- blackish biofilms (BB), usually arising from cyanobacterial and fungal colonisations;

- lichen crusts (LC), as circular elements of lighter colour inside wide blackish areas;

- weeds, shrubs and arboreal flora (WS), detectable by a more complex organisation, with evident stems and leaves (sometimes also flowers). In these areas, the presence of mosses' pulvines can also likely be expected.

All the exposures showed diffuse BPs with variations during the old documented periods, likely as a result of restoration activities. The growth of higher plants between the blocks was significant in the oldest centuries, while a diffuse biological blackening is still evident in more recent times, particularly in the first half of the 20th century.

Photographic material of the 1990s showed subcircular tracks-in most cases of approximate 5-10 cm diameter, but sometimes larger in size-which remained free from surrounding growths (Figure 3c) or, sometimes, displayed a growth of black bio-patinas in the central parts of clearer areas (Figure $3 \mathrm{a}, \mathrm{b}$ ). 


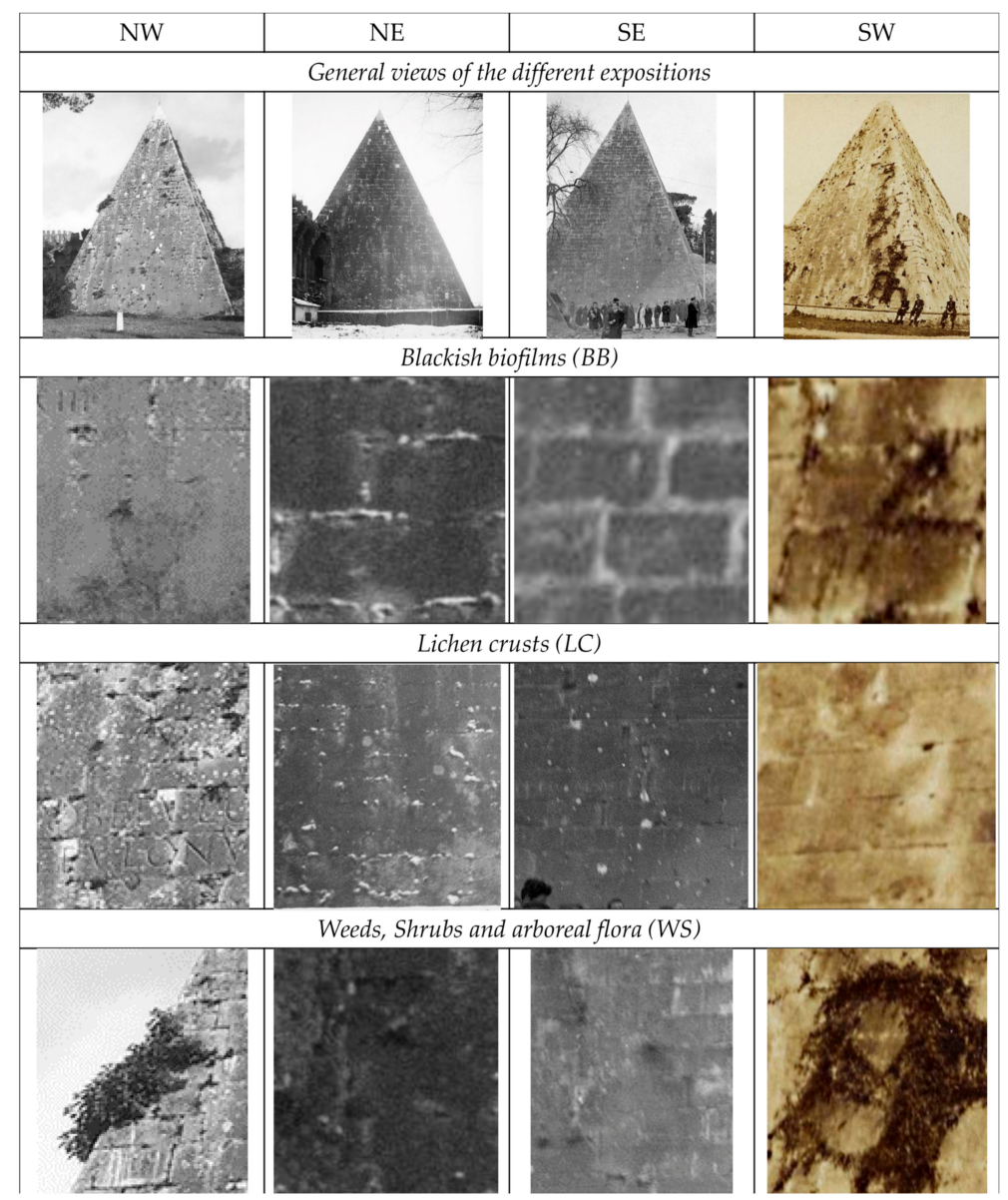

Figure 2. Selection of biodeterioration patterns (BPs) at different exposures from the end of 19th to the first half of 20th century: Northwest (NW) -1920-1930 (Alinari Archives, ACA-F-028699-0000); Northeast (NE) - 1890 (Fondazione Primoli, 6639/A); Southeast (SE)—03-07/03/1944 (Alinari Archives, AIL-S-000659-0038); Southwest (SW) -1880-1890 (Alinari Archives, FVQ-F-042444-0000). The block height is approximately $50 \mathrm{~cm}$.

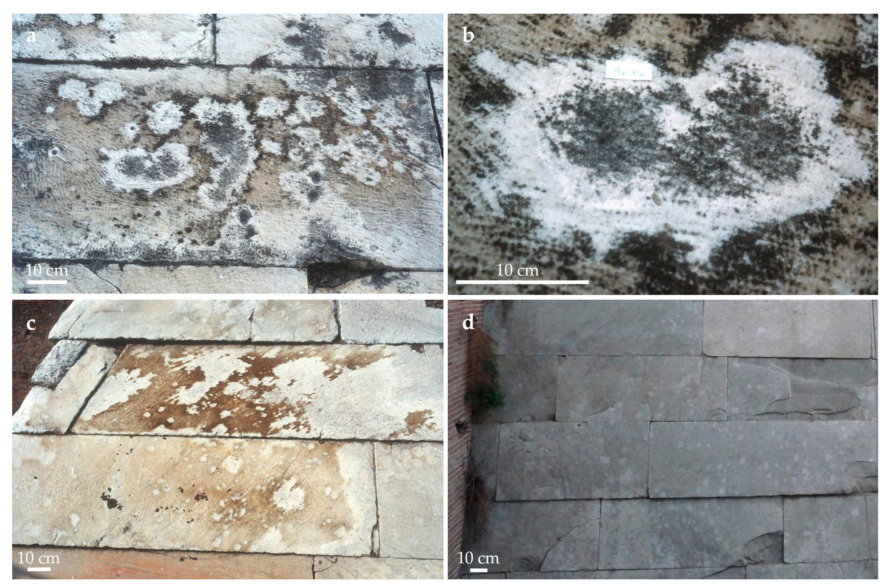

Figure 3. (a,b) BPs hypothetically related to previous lichen colonisation, and biofilm regrowth in their central areas (1990s); (c) BPs hypothetically related to lichen cover detachment (whitish surfaces) surrounded by brownish patinas (1990s); (d) BPs (whitish circular areas) hypothetically related to the past occurrence of lichen thalli, where the microbial recolonisation does not occur (2017). The block height is approximately $50 \mathrm{~cm}$. 
The morphology and size of such whitish areas seem compatible with the tracks of past lichen presence, which was no longer detectable on those blocks. In other portions of the walls, residues of some still living thalli of foliose cyanolichens (Figure 4a) and crustose chlorolichens were instead observed. These latter are potentially compatible with species of genera Aspicilia s.l. (Figure 4b) and Verrucaria s.l. (Figure 4c), and endolithic species responsible for pitting (Figure 4d).
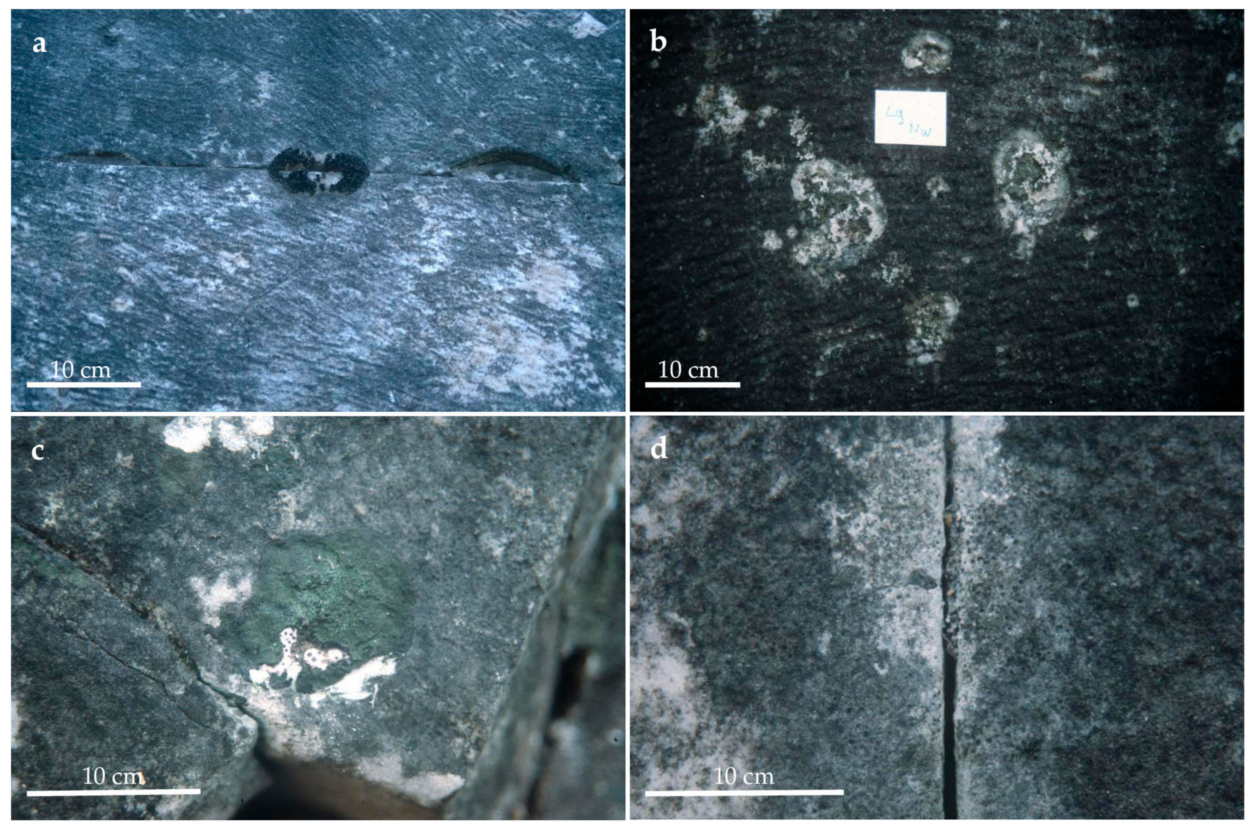

Figure 4. Lichens on the Pyramid before the restoration in the 1990s. Thallus morphology is potentially compatible with: (a) cyanolichens; (b) Aspicilia s.l.; (c) Verrucaria s.l.; and (d) endolithic species.

In recent photographs of 2017, tracks of lighter, uncolonised areas, which potentially delineate the shapes of past centimetric subcircular thalli, are still detectable on different exposures of the Pyramid (Figure 3d).

The decrease of biological colonisation in recent years can be explained taking into account several factors. In the first place, it is likely related to the increase in atmospheric pollution, considering its relevance in reducing biodiversity [53] and allowing only a few resistant organisms to survive when the microclimate is favourable [19]. Other negative factors were the above-mentioned reduction of humidity and rainfalls, as well as the increase in the temperature, which occurred in the last few decades, due to climatic changes and urban development $[55,56]$. Finally, restoration activities with traditional biocide treatments, which are carried out with higher frequency [44], contribute to maintaining the monument free from microbial colonisation.

\subsection{Hypothesis on the Aetiological Agent of the Tracks}

A lichen vegetation survey carried out during the 1980s through 16 archaeological sites of Latium displayed the total presence of 284 taxa [45]. Details on the distribution reported for each species clarify the peculiar association of 90 taxa with carbonate substrates, including travertine, hard and soft limestone, and marble. Figure 5 considers the morphological features and the production of secondary metabolites for these taxa, which may support or exclude their potential aetiological role in the development of the centimetric tracks of uncolonised surface (complete list of species in Supplementary Materials). 


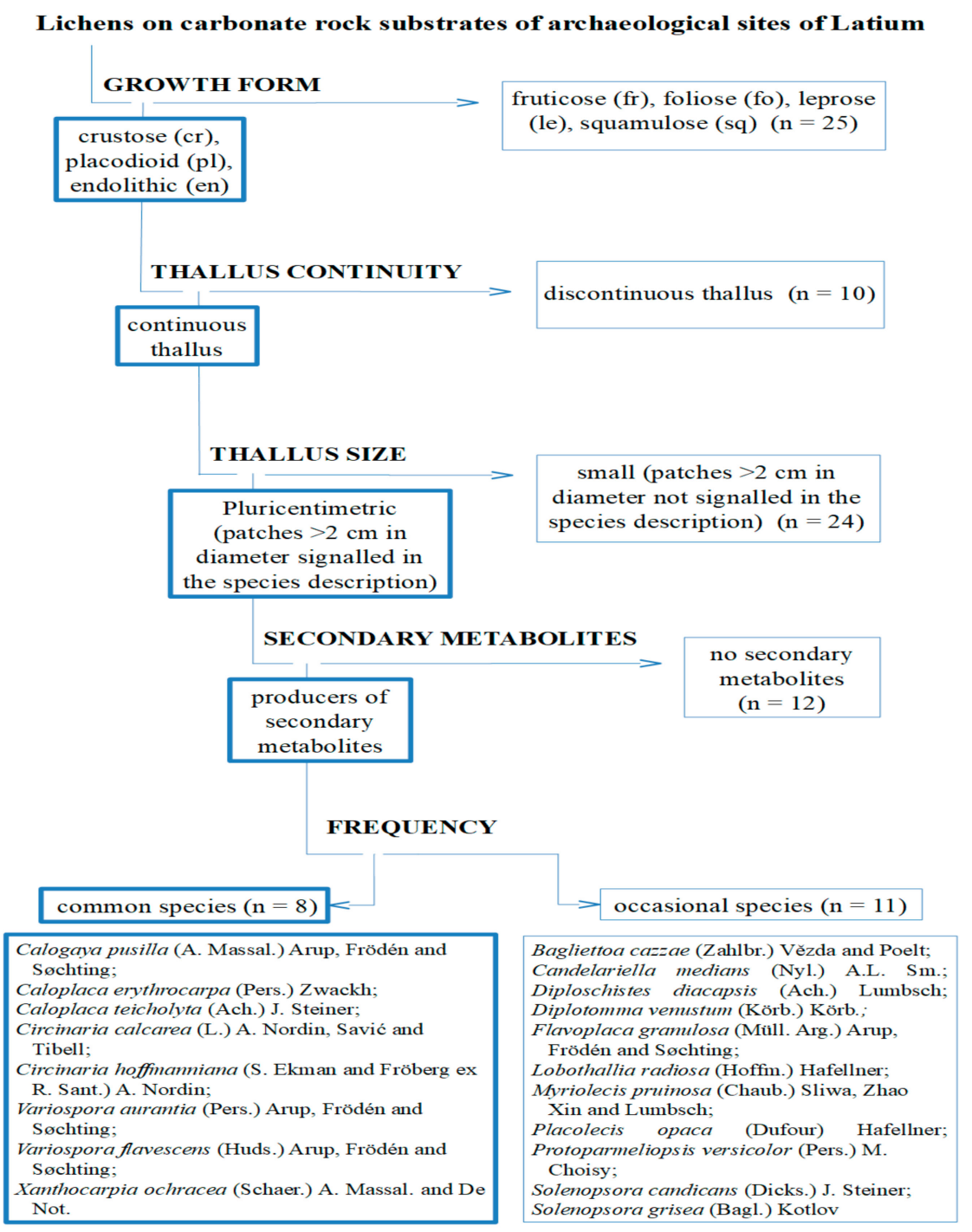

Figure 5. Lichens reported on carbonate rock substrates of archaeological sites of Latium [45], examined with respect to morphological and physiological traits potentially related with their recognition as aetiological factor for the development of the tracks of uncolonised surface (complete list of species in Supplementary Materials).

Sixty-five species display a growth-form compatible with a strict thallus adhesion and a deep interaction with the substrate, including epilithic crustose $(n=34)$ and crustose-placodioid $(n=12)$ species, and endolithic crustose ones $(n=19)$. Fruticose, foliose and leprose species $(n=25)$ generally show a limited and discontinuous contact with the rock substrate [4], which cannot be confidently associated with the continuity of uncolonised surfaces. Similarly, only 55 of the crustose species usually show continuous thalli, and only 31 of them generally show pluricentimetric thalli (patches $>2 \mathrm{~cm}$ ), which may be compatible with the size of the tracks [45-47]. In this last group, twelve species do not produce any secondary metabolite, while the remnant 19 are known to produce secondary metabolites, at least in a part of vegetative or reproductive structures. On the basis of the reference vegetation survey [45], eight of these species are common on the carbonate stone surfaces, while an occasional occurrence characterises the other taxa.

Ecological indicator values [48] of all the 8 common taxa generally indicate a rather high to high xerophytism and tolerance for atmospheric pollution (Table 2), which are compatible with their presence in the area of Rome and the recent trend of climatic and atmospheric conditions. A strongly xerophytic and moderately nitrophytic lichen flora was also reported from Colosseum at the end of 
the 20th century [46], while a higher number of hygrophytic species had been reported at the end of the 19th century [47].

Table 2. Lichen species hypothesised on the Caestia Pyramid and their ecological indicator values.

\begin{tabular}{cccccc}
\hline Species & $\mathbf{p H}$ & Solar Irradiation & Aridity & Eutrophication & Poleotolerance \\
\hline Calogaya pusilla & $3-5$ & $4-5$ & $4-5$ & $2-3$ & $1-3$ \\
Caloplaca erythrocarpa & $4-5$ & $4-5$ & 4 & $2-3$ & $1-2$ \\
Caloplaca teicholyta & $3-4$ & $3-4$ & 3 & $3-4$ & $2-3$ \\
Circinaria calcarea & $4-5$ & $3-5$ & 4 & $2-3$ & $1-2$ \\
$\quad$ Circinaria & $3-5$ & $3-5$ & $3-4$ & $3-5$ & $1-3$ \\
hoffmanniana & $4-5$ & $4-5$ & $4-5$ & $3-4$ & $1-3$ \\
Variospora aurantia & $3-5$ & $3-4$ & $3-4$ & $1-3$ \\
Variospora flavescens & $4-5$ & $2-4$ & 3 & $1-2$ & $1-3$ \\
Xanthocarpia ochracea & 5 & & 2 & & \\
\hline
\end{tabular}

Indicator scales according to Nimis [48] for: $\mathrm{pH}$ of the substrate: 3, on subacid to subneutral; 4, on slightly basic; 5 , on basic; solar irradiation (s.i.): 2 , in shaded situations; 3 , in plenty of diffuse light but scarce direct s.i.; 4 , in sun-exposition, but avoiding extreme s.i.; 5 , very high direct s.i.; aridity: 3 , mesophytic; 4 , xerophytic, but not in extreme aridity; 5 , very xerophytic; eutrophication (eu): 2 , resistant to a very weak eu; 3 , resistant to a weak eu; 4 , in rather eu; 5 , in highly eu; (v) poleotolerance: 1 , in natural or semi-natural habitats; 2 , in moderately disturbed areas; 3 , in heavily disturbed areas.

In particular, six species of genera Calogaya, Caloplaca, Variospora and Xanthocarpia (grouped in the former genus Caloplaca s.l. before the revision by Arup et al. [57])—all producing antraquinones, including parietin $\left(\mathrm{C}_{16} \mathrm{H}_{12} \mathrm{O}_{5}\right.$, Figure $6 \mathrm{a}$ ) - and two species of genus Circinaria (belonging to genus Aspicilia s.l. before the revision by Nordin et al. [58])—producing the polydroxylate macrolide aspicilin $\left(\mathrm{C}_{18} \mathrm{H}_{32} \mathrm{O}_{5}\right.$, Figure $\left.6 \mathrm{~b}\right)$-were listed. It is worth noting that both Circinaria species also secrete oxalic acid, producing oxalate deposits within the thallus and at the rock interface $[22,23,59]$.
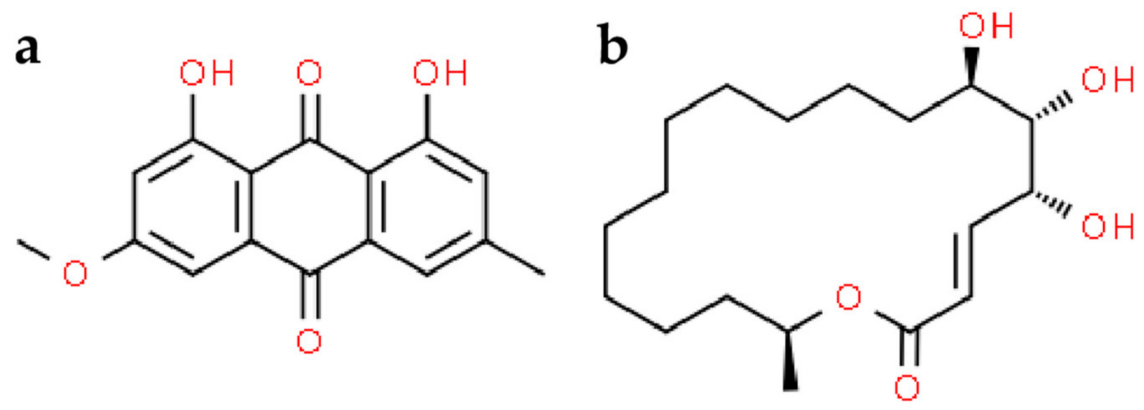

Figure 6. Chemical structure of parietin (a) and aspicilin (b).

With reference to the ecological indicator values, Variospora species, Calogaya pusilla and Circinaria hoffmaniana are more remarkably tolerant of strong aridity, direct solar irradiation, very high eutrophication and air pollution, likely associated to the microenvironment of the Pyramid walls. Nevertheless, only thalli compatible with Aspicilia s.l. were observed in the photographic material, while the presence of thalli of the Caloplaca s.l. group was never documented. Remarkably, Variospora flavescens and Circinaria calcarea were also observed in the 1990s on mortars in the Colosseum [46], and the latter species was already reported in the first floristic list dating to the end of the 19th century [47].

The eleven occasional species include producers of a wider set of secondary metabolites, such as depsidones (norstictic acid, psoromic acid, unidentified), depsides (lecanoric acid, diploschistesic acid), furandiones (usnic acid), pulvinic acid derivatives, xanthones (arthotelin, 2.7-dichloronorlichexanthone), terpenoids (zeorin) and aliphatic compounds (murolic acid).

The probable long-lasting growth-inhibition efficacy of lichens is supported by the known allelopathic activity of some of their secondary metabolites (see Section 3.3 below) and the characteristics 
of the tracks. Moreover, spectroscopic investigations have been performed in parallel on carbonate heritage surfaces in Italy, others than the Pyramid, but analogously characterised by circular centimetric areas unaffected by the surrounding development of black biofilms [52]. In that case, thalli of Circinaria calcarea were still abundant nearby, and UV observations and Raman spectra compatible with aspicilin were obtained in the field and from material scraped from the uncolonised tracks, respectively.

On the Pyramid, the inhibitory effects—which are more evident on the borders of some tracks—can be explained considering the higher and more recent metabolic activity in the younger peripheral parts of thalli [60]. A complementary hypothesis is that the previous surface colonisation and the related hyphal penetration and chemical deterioration (e.g., by oxalic acid) may have predominantly modified the stone substrate and increased its bioreceptivity in the parts covered by the oldest parts of the thallus [61], prevailing on the inhibitory effect. However, this phenomenon is not generalisable, because in the centre of some tracks, we do not detect regrowth of bio-patinas (Figure 3c). For this reason, a difference in physical interactions does not thus seem sufficient to explain the differential growth inside and outside the circular tracks, whereas chemical differences due to different secondary metabolites produced by different lichens appear more likely to be aetiological agents.

\subsection{The selection of Promising Substances}

Biological activities of the secondary metabolites produced by lichen species reported on carbonate rock surfaces of Latium archaeological areas and having thalli compatible with the uncolonised tracks observed on the Pyramid are listed in Table 3.

Table 3. Biological activities of the secondary metabolites produced by the lichen species recognised as possible past colonisers of the Pyramid.

\begin{tabular}{|c|c|c|c|c|c|}
\hline \multicolumn{3}{|l|}{ Lichen Compounds } & \multirow{2}{*}{$\begin{array}{c}\text { Candidate Coloniser(s) } \\
\text { of the Pyramid }\end{array}$} & \multirow{2}{*}{ Biological Activity } & \multirow{2}{*}{ Reference } \\
\hline Category & Metabolite & Formula & & & \\
\hline $\begin{array}{l}\text { Polydroxylated } \\
\text { macrolide }\end{array}$ & Aspicilin & $\mathrm{C}_{18} \mathrm{H}_{32} \mathrm{O}_{5}$ & $\begin{array}{l}\text { Circinaria calcarea, } \\
\text { Circinaria hoffmaniana }\end{array}$ & $\begin{array}{l}\text { * Antibacterial activity, } \\
\text { and phytotoxicity } \\
\text { (inhibition of } \\
\text { cholesterol biosynthesis } \\
\text { and microfilament } \\
\text { formation, antimalarial) }\end{array}$ & [62] \\
\hline Antraquinones & Parietin (e.g.) & $\mathrm{C}_{16} \mathrm{H}_{12} \mathrm{O}_{5}$ & $\begin{array}{c}\text { Calogaya pusilla, } \\
\text { Caloplaca erythrocarpa, } \\
\text { Caloplaca teicholyta, } \\
\text { Flavoplaca granulosa, } \\
\text { Placolecis opaca (medulla), } \\
\text { Variospora aurantia, } \\
\text { Variospora flavescens, } \\
\text { Xanthocarpia ochracea }\end{array}$ & $\begin{array}{l}\text { ** antibacterial agent, } \\
\text { antifungal agent, } \\
\text { (apoptosis inducer, } \\
\text { antineoplastic agent, } \\
\text { hepatoprotective agent, } \\
\text { anti-inflammatory agent) }\end{array}$ & [63] \\
\hline Depsidones & Norstictic acid & $\mathrm{C}_{18} \mathrm{H}_{12} \mathrm{O}_{9}$ & Diplotomma venustum & $\begin{array}{l}{ }^{*} \text { antimicrobial } \\
\text { (antioxidant, anticancer) }\end{array}$ & [64] \\
\hline \multirow{3}{*}{ Depsides } & Psoromic acid & $\mathrm{C}_{18} \mathrm{H}_{14} \mathrm{O}_{8}$ & $\begin{array}{l}\text { Protoparmeliopsis } \\
\text { versicolor (medulla) }\end{array}$ & $\begin{array}{l}\text { * antifungal activity } \\
\text { (apoptotic activity) }\end{array}$ & {$[65,66]$} \\
\hline & Lecanoric acid & $\mathrm{C}_{16} \mathrm{H}_{14} \mathrm{O}_{7}$ & Diploschistes diacapsis & $\begin{array}{c}\text { * antibacterial, } \\
\text { and antifungal } \\
\text { (antitumor, antioxidant) }\end{array}$ & [67] \\
\hline & Diploschistesic acid & $\mathrm{C}_{16} \mathrm{H}_{14} \mathrm{O}_{8}$ & Diploschistes diacapsis & $\begin{array}{l}\text { not reported (at the best } \\
\text { of our knowledge) }\end{array}$ & - \\
\hline Furandiones & Usnic acid & $\mathrm{C}_{18} \mathrm{H}_{16} \mathrm{O}_{7}$ & $\begin{array}{l}\text { Protoparmeliopsis } \\
\text { versicolor (cortex) }\end{array}$ & $\begin{array}{c}\text { * antibacterial, } \\
\text { antifungal } \\
\text { (antiviral, antitumour, } \\
\text { antioxidant, } \\
\text { antipyretic, analgetic, } \\
\text { anti-inflammatory, } \\
\text { hepatotoxic, } \\
\text { antiviral) }\end{array}$ & {$[63,68]$} \\
\hline $\begin{array}{l}\text { Pulvinic acid } \\
\text { derivatives }\end{array}$ & Calycin (e.g.) & $\mathrm{C}_{18} \mathrm{H}_{10} \mathrm{O}_{5}$ & Candelariella medians & $\begin{array}{l}\text { ** (antioxidant, } \\
\text { photoprotection) }\end{array}$ & [69] \\
\hline Xanthones & $\begin{array}{c}\text { Arthothelin } \\
\text { 2.7-dichloronorlichexanthone }\end{array}$ & $\begin{array}{l}\mathrm{C}_{14} \mathrm{H}_{7} \mathrm{C}_{13} \mathrm{O}_{5} \\
\mathrm{C}_{14} \mathrm{H}_{8} \mathrm{C}_{12} \mathrm{O}_{5}\end{array}$ & $\begin{array}{l}\text { Myriolecis pruinosa } \\
\text { Myrolecis pruinosa }\end{array}$ & $\begin{array}{c}* * \text { antimicrobial } \\
\text { (antioxidant, cytotoxic) }\end{array}$ & [70] \\
\hline
\end{tabular}


Table 3. Cont.

\begin{tabular}{ccccc}
\hline Lichen Compounds & Metabolite & Formula & $\begin{array}{c}\text { Candidate Coloniser(s) } \\
\text { of the Pyramid }\end{array}$ & Biological Activity \\
\hline Category & Zeorin & $\mathrm{C}_{30} \mathrm{H}_{52} \mathrm{O}_{2}$ & $\begin{array}{c}\text { Protoparmeliopsis } \\
\text { versicolor (medulla) }\end{array}$ & $\begin{array}{c}\text { *antibacterial, } \\
\text { antifungal } \\
\text { (antioxidant) }\end{array}$ \\
$\begin{array}{c}\text { Aliphatic } \\
\text { compounds }\end{array}$ & Murolic acid & $\mathrm{C}_{21} \mathrm{H}_{36} \mathrm{O}_{5}$ & $\begin{array}{c}\text { Protoparmeliopsis } \\
\text { versicolor (medulla) }\end{array}$ & $\begin{array}{c}\text { not reported (at the best } \\
\text { of our knowledge) }\end{array}$ \\
\hline
\end{tabular}

* Biological properties reported for the metabolite category; ${ }^{* *}$ Biological properties reported for the specific metabolite. Parietin, the antraquinone produced by all the Caloplaca s.l. species, is a well-known sun-screening compound [71], which protects thalli from excessive radiation, but it already revealed several additional potencies, including antibacterial and antifungal activities [63].

Aspicilin, produced by Circinaria species, has long been considered an attractive target to test synthetic methodologies, but its biological functions are still unknown. However, antibacterial activity and phytotoxicity were generally recognised for polyhydroxylated macrolides [62].

Antimicrobial functions, including antibacterial and antifungal ones, are known also for several secondary metabolites of the other species putatively related to the Pyramid tracks on the basis of distribution and morphological features, as for norstictic and psoromic acids (depsidones), lecanoric acid (depside), zeorin (terpenoid) and usnic acid (furandione).

Such data appear to be of great interest for monument conservation, considering that significant efforts have been made so far in order to control and hinder biodeterioration, often by means of biocides [36-38]. Traditional biocides have been used for a long time, but their extensive or inappropriate use may have negative implications [36,37]. Safer biocides are needed, in particular to protect the health of the operators - who handle big amounts of chemicals—-to enhance environmental sustainability, and to preserve the integrity of the materials [38]. Such allelopathic compounds, produced by the putative past colonisers of the Pyramid, and in particular the macrolide aspicilin produced together with oxalates by Circinaria species, could be the source of new active principles to be tested for stone conservation. According to the recent proposals dealing with natural biocides [38], even very low doses of lichen metabolites seem to be valuable candidates as treatments to extend the efficacy of stone cleaning interventions [35]. Their natural long-lasting activity appears to be a further crucial element of economical sustainability in stone restoration. However, tests on their efficacy range and on the actual absence of interaction with materials or toxic effects on human health, poorly tested for such compounds, will be needed before their introduction in the field.

\section{Conclusions}

The observations and analyses of the rich archives of historical photographs available for the Caestia Pyramid in Rome suggested a lichen origin for the peculiar tracks characterised by evident inhibition areas for the growth of new bio-patinas. A precise evaluation of the changes over time in the cover of each $\mathrm{BP}$ will be the aim of a further contribution on the historical analysis of the monument. Considering the morphology, the biochemical properties and the historical data on lichens, occurring in Latium archaeological sites and monuments in 1980s and 1990s, we suppose that the tracks resulting from the secretion of allelopathic compounds by lichens mainly belong to the genus Circinaria (Aspicilia s.l.).

These results seem relevant to highlight the long-lasting allopathic properties of some lichen substances and to suggest further tests for an evaluation of their potential application as natural products to reduce stone monument colonisation. Considering their origin and activity, the environmental and economic sustainability of such compounds in the field of stone restoration seems promising.

Supplementary Materials: The following are available online at http://www.mdpi.com/2071-1050/12/3/1132/s1, Complete list of lichens reported on carbonate rock substrates of archaeological sites of Latium [45], examined with respect to morphological and physiological traits potentially related with their recognition as aetiological factor for the development of the tracks of uncolonised surface.

Author Contributions: Conceptualization, G.C. and S.E.F.-L.; Data curation, G.C., M.R.F., C.T. and S.E.F.-L.; Formal analysis, G.C., C.T. and S.E.F.-L.; Funding acquisition, G.C.; Investigation, G.C., M.R.F., C.T. and S.E.F.-L.; 
Methodology, G.C., M.R.F., C.T. and S.E.F.-L.; Project administration, G.C. and S.E.F.-L.; Resources, M.R.F. and S.E.F.-L.; Supervision, G.C. and S.E.F.-L.; Validation, G.C. and S.E.F.-L.; Writing - original draft, G.C., M.R.F., C.T. and S.E.F.-L.; Writing - review \& editing, G.C., M.R.F., C.T. and S.E.F.-L. All authors have read and agreed to the published version of the manuscript.

Funding: The Grant of Excellence Departments, MIUR-Italy (ARTICOLO 1, COMMI 314-337 LEGGE 232/2016) and the Grant of Regione Lazio under the SUPERARE grant "Gruppi di Ricerca" (Convenzione prot. n. 85- 2017-14854-CUP: F86C18000650005-L.R. 13/2008-art. 4-Avviso Pubblico "PROGETTI DI GRUPPI DI RICERCA-Conoscenza e cooperazione per un nuovo modello di sviluppo") are gratefully acknowledged. The research was also supported by the Italian Ministry of Education, University and Research (MIUR) through Ph.D. grants of Roma Tre University (Rome, Italy) and University of Torino (Torino, Italy).

Conflicts of Interest: The authors declare no conflict of interest. The funders had no role in the design of the study; in the collection, analyses, or interpretation of data; in the writing of the manuscript, or in the decision to publish the results.

\section{References}

1. Caneva, G.; Nugari, M.P.; Salvadori, O. Plant Biology for Cultural Heritage: Biodeterioration and Conservation; The Getty Conservation Institute: Los Angeles, CA, USA, 2008.

2. Di Carlo, E.; Barresi, G.; Palla, F. Biodeterioration. In Biotechnology and Conservation of Cultural Heritage; Palla, F., Barresi, G., Eds.; Springer International Publishing: Cham, Switzerland, 2017; pp. 1-30.

3. Macedo, M.F.; Miller, A.Z.; Dionísio, A.; Saiz-Jimenez, C. Biodiversity of cyanobacteria and green algae on monuments in the Mediterranean Basin: An overview. Microbiology 2009, 155, 3476-3490. [CrossRef] [PubMed]

4. Salvadori, O.; Casanova-Municchia, A. The Role of Fungi and Lichens in the Biodeterioration of Stone Monuments. Open Conf. Proc. J. 2016, 7, 39-54. [CrossRef]

5. Seaward, M.R.D. Lichens as Subversive Agents of Biodeterioration. In Biodeterioration of Stone Surfaces; Seaward, M.R.D., St. Clair, L.L., Eds.; Springer: Dordrecht, The Netherlands, 2004; pp. 9-18.

6. Seaward, M.R.D. Lichens as Agents of Biodeterioration. In Recent Advances in Lichenology; Upreti, D., Divakar, P., Shukla, V., Bajpai, R., Eds.; Springer India: New Delhi, India, 2015; Volume 3, pp. 189-211. [CrossRef]

7. Carter, N.E.A.; Viles, H.A. Experimental investigations into the interactions between moisture, rock surface temperatures and an epilithic lichen cover in the bioprotection of limestone. Build. Environ. 2003, 38, 1225-1234. [CrossRef]

8. Carter, N.E.A.; Viles, H.A. Bioprotection explored: The story of a little known earth surface process. Geomorphology 2005, 67, 273-281. [CrossRef]

9. Bartoli, F.; Casanova Municchia, A.; Futagami, Y.; Kashiwadani, H.; Moon, K.H.; Caneva, G. Biological colonization patterns on the ruins of Angkor temples (Cambodia) in the biodeterioration vs bioprotection debate. Int. Biodeterior. Biodegrad. 2014, 96, 157-165. [CrossRef]

10. Casanova Municchia, A.; Bartoli, F.; Taniguchi, Y.; Giordani, P.; Caneva, G. Evaluation of the biodeterioration activity of lichens in the Cave Church of Üzümlü (Cappadocia, Turkey). Int. Biodeterior. Biodegrad. 2018, 127, 160-169. [CrossRef]

11. Caneva, G.; Salvadori, O.; Ricci, S.; Ceschin, S. Ecological analysis and biodeterioration processes over time at the Hieroglyphic Stairway in the Copàn (Honduras) archaeological site. Plant Biosyst. 2005, 139, 295-310. [CrossRef]

12. Caneva, G.; Bartoli, F.; Savo, V.; Futagami, Y.; Strona, G. Combining Statistical Tools and Ecological Assessments in the Study of Biodeterioration Patterns of Stone Temples in Angkor (Cambodia). Sci. Rep. 2016, 6, 32601. [CrossRef]

13. Danin, A.; Garty, J. Distribution of cyanobacteria and lichens on hillsides of the Negev Highlands and their impact on biogenic weathering. Z. Geomorph. N. F. 1983, 27, 423-444.

14. Danin, A.; Gerson, R.; Garty, J. Weathering patterns on hard limestone and dolomite by endolithic lichens and cyanobacteria: supporting evidence for eolian contribution to terra rossa soil. Soil Sci. 1983, 136, $213-217$. [CrossRef]

15. Danin, A. Palaeoclimates in Israel: Evidence from Weathering Patterns of Stones In and Near Archaeological Sites. BASOR 1985, 259, 33-43. [CrossRef]

16. Caneva, G.; Danin, A.; Ricci, S.; Conti, C. The pitting of Trajan's column, Rome: An ecological model of its origin. In Conservazione del Patrimonio culturale II, Contributi Centro Linceo Interdisciplinare Beniamino Segre; Accademia Nazionale dei Lincei: Rome, Italy, 1994. 
17. Caneva, G.; Nugari, M.P.; Ricci, S.; Salvadori, O. Pitting of marble Roman monuments and the related microflora. In Proceedings of the VII International Symposium on Deterioration and Conservation of Stone, Lisbon, Portugal, 15-18 June 1992; pp. 521-530.

18. Camuffo, D. Reconstructing the climate and the air pollution of Rome during the life of the Trajan Column. Sci. Total Environ. 1993, 128, 205-226. [CrossRef]

19. Caneva, G.; Gori, E.; Montefinale, T. Biodeterioration of monuments in relation to climatic changes in Rome between 19-20th centuries. Sci. Total Environ. 1995, 167, 205-214. [CrossRef]

20. Monge-Nájera, J.; Morera-Brenes, B. Biodeterioration and Biodegradation of Roman Monuments: A Comparison of the Current Status of 18th Century Paintings by The Canalettos. Int. J. Conserv. Sci. 2014, 5, 3-8.

21. Pinna, D.; Salvadori, O.; Tretiach, M. An anatomical investigation of calcicolous endolithic lichens from the Trieste karst (NE Italy). Plant Biosyst. 1998, 132, 183-195. [CrossRef]

22. Edwards, H.G.M.; Russell, N.C.; Seaward, M.R.D. Calcium oxalate in lichen biodeterioration studied using FT-Raman spectroscopy. Spectrochim. Acta Part A 1997, 53, 99-105. [CrossRef]

23. Edwards, H.G.M.; Seaward, M.R.D.; Attwood, S.J.; Little, S.J.; de Oliveira, L.F.C.; Tretiach, M. FT-Raman spectroscopy of lichens on dolomitic rocks: an assessment of metal oxalate formation. Analyst 2003, 128, 1218-1221. [CrossRef] [PubMed]

24. Caneva, G. Ecological approach to the genesis of calcium oxalate patinas on stone monuments. Aerobiologia 1993, 9, 149-156. [CrossRef]

25. Lokajová, V.; Bačkorová, M.; Bačkor, M. Allelopathic effects of lichen secondary metabolites and their naturally occurring mixtures on cultures of aposymbiotically grown lichen photobiont Trebouxia erici (Chlorophyta). S. Afr. J. Bot. 2014, 93, 86-91. [CrossRef]

26. Molnár, K.; Farkas, E. Current Results on Biological Activities of Lichen Secondary Metabolites: A Review. Z. Naturforsch. C. 2010, 65, 157-173. [CrossRef]

27. Prashith Kekuda, T.R.; Vinayaka, K.S.; Sachin, M.B. Chemistry, ethnobotanical uses and biological activities of the lichen genus Heterodermia trevis. (Physciaceae; Lecanorales; Ascomycota): A comprehensive review. J. Appl. Pharm. Sci. 2018, 8, 148-155. [CrossRef]

28. Yamamoto, Y.; Hara, K.; Kawakami, H.; Komine, M. Lichen Substances and Their Biological Activities. In Recent Advances in Lichenology; Upreti, D., Divakar, P., Shukla, V., Bajpai, R., Eds.; Springer: New Delhi, India, 2015; Volume 2, pp. 181-199. [CrossRef]

29. Lawrey, J.D. Biology of Lichenized Fungi; Praeger Publishers: New York, NY, USA, 1984.

30. Favero-Longo, S.E.; Piervittori, R. Lichen-plant interactions. J. Plant Interact. 2010, 5, 163-177. [CrossRef]

31. Lawrey, J.D. Biotic Interactions in Lichen Community Development: A Review. Lichenologist 1991, 23, 205-214. [CrossRef]

32. Lawrey, J.D. Lichen Allelopathy-A Review. Allelopath. ACS Symp. Ser. 1994, 582, 26-38. [CrossRef]

33. Ascaso, C.; Galvan, J. Studies on the pedogenetic action of lichen acids. Pedobiologia 1976, 16, 321-331.

34. Turci, F.; Favero-Longo, S.E.; Tomatis, M.; Martra, G.; Castelli, D.; Piervittori, R.; Fubini, B. A Biomimetic Approach to the Chemical Inactivation of Chrysotile Fibres by Lichen Metabolites. Chem. Eur. J. 2007, 13, 4081-4093. [CrossRef]

35. Gazzano, C.; Favero-Longo, S.E.; Iacomussi, P.; Piervittori, R. Biocidal effect of lichen secondary metabolites against rock-dwelling microcolonial fungi, cyanobacteria and green algae. Int. Biodeterior. Biodegrad. 2013, 84, 300-306. [CrossRef]

36. Caneva, G.; Nugari, M.P.; Pinna, D.; Salvadori, O. Il Controllo del Degrado Biologico: i Biocidi Nel Restauro dei Materiali Lapidei; Nardini Editore: Fiesole, Italy, 1996.

37. Pinna, D. Coping with Biological Growth on Stone Heritage Objects: Methods, Products, Applications, and Perspectives; Apple Academic Press: Waretown, NJ, USA, 2017.

38. Fidanza, M.R.; Caneva, G. Natural biocides for the conservation of stone cultural heritage: A review. J. Cult. Herit. 2019, 38, 271-286. [CrossRef]

39. Claridge, A.; Toms, J.; Cubberley, T. Rome: An Oxford Archaeological Guide, 2nd ed.; Oxford University Press: Oxford, UK, 2010.

40. Franzini, M.; Lezzerini, M. The Triassic marble from the Punta Bianca promontory (La Spezia, Italy). Did Roman quarrying of "Lunensis marble" begin here? Period. Mineral. 2002, 71, 137-144.

41. Serra, J. Sul restauro della Piramide di C. Cestio nel 1663. Bollettino dell'Istituto Centrale del Restauro 1957, 31, $173-181$.

42. Saiz-Jimenez, C. Microbial melanins in stone monuments. Sci. Total Environ. 1995, 167, 273-286. [CrossRef] 
43. Golubić, S.; Pietrini, A.M.; Ricci, S. Euendolithic activity of the cyanobacterium Chroococcus lithophilus Erc. In biodeterioration of the Pyramid of Caius Caestius, Rome, Italy. Int. Biodeterior. Biodegrad. 2015, 100, 7-16. [CrossRef]

44. Giovagnoli, A.; Nugari, M.P.; Pietrini, A.M. The Ice Clean system for removing biological patina: The case of Piramide of Caio Cestio in Rome. In Proceedings of the International Conference on non-destructive investigations and microanalysis for the diagnostics and conservation of cultural and environmental heritage (ART 2011), Florence, Italy, 13-15 April 2011. Foresti, Brescia, Italy.

45. Nimis, P.L.; Monte, M.; Tretiach, M. Flora e vegetazione lichenica di aree archeologiche del Lazio. Studia Geobot. 1987, 7, 3-161.

46. Bartoli, A. I licheni del Colosseo. Allionia 1997, 35, 59-67.

47. Fiorini Mazzanti, E. Florula del Colosseo. Atti dell'Accademia Pontificia dei Nuovi Lincei 1875, 31, 157-162.

48. Nimis, P.L. The Lichens of Italy. A Second Annotated Catalogue; EUT: Trieste, Italy, 2016.

49. ITALIC. ITALIC-The Information System on Italian Lichens, version 5.0.; University of Trieste: Trieste, Italy, 2017.

50. Smith, C.W.; Aptroot, A.; Coppins, B.J.; Fletcher, A.; Gilbert, O.L.; James, P.W.; Wolseley, P.A. The Lichens of Great Britain and Ireland, 2nd ed.; British Lichen Society: London, UK, 2009.

51. Culberson, C.F. Chemical and Botanical Guide to Lichen Products, Reprint; Otto Koeltz Science Publishers: Koenigstein, Germany, 1979.

52. Favero-Longo, S.E.; Tonon, C.; Fidanza, M.R.; Caneva, G. Long-Lasting Allelopathic Effect of Circinaria-secreted Aspicilin on Carbonate Substrates. In Unlocking the Inner Lichen, Proceedings of the International Association for Lichenology 9th Symposium, Bonito, Brazil, 2-7 August 2020; IAL: Bonito, Brazil, 2020.

53. Kim, S.; Thiessen, P.A.; Bolton, E.E.; Chen, J.; Fu, G.; Gindulyte, A.; Han, L.; He, J.; He, S.; Shoemaker, B.A.; et al. PubChem Substance and Compound databases. Nucleic Acids Res. 2016, 44, D1202-D1213. [CrossRef] [PubMed]

54. Mitchell, R.; Gu, J.D. Changes in the biofilm microflora of limestone caused by atmospheric pollutants. Int. Biodeterior. Biodegrad. 2000, 46, 299-303. [CrossRef]

55. Caneva, G.; Pacini, A.; Cutini, M.; Merante, A. The Colosseum floras as bio-indicators of the climatic changes in Rome. Clim. Change 2005, 70, 431-443. [CrossRef]

56. Moonen, A.C.; Ercoli, L.; Mariotti, M.; Masoni, A. Climate change in Italy indicated by agrometeorological indices over 122 years. Agric. For. Meteorol. 2002, 111, 13-27. [CrossRef]

57. Arup, U.; Søchting, U.; Frödén, P. A new taxonomy of the family Teloschistaceae. Nord. J. Bot. 2013, 31, 16-83. [CrossRef]

58. Nordin, A.; Savić, S.; Tibell, L. Phylogeny and taxonomy of Aspicilia and Megasporaceae. Mycologia 2010, 102, 1339-1349. [CrossRef] [PubMed]

59. Frank-Kamenetskaya, O.V.; Ivanyuk, G.Y.; Zelenskaya, M.S.; Izatulina, A.R.; Kalashnikov, A.O.; Vlasov, D.Y.; Polyanskaya, E.I. Calcium Oxalates in Lichens on Surface of Apatite-Nepheline Ore (Kola Peninsula, Russia). Minerals 2019, 9, 656. [CrossRef]

60. Benatti, M.N.; Gernert, M.; Schmitt, I. Parmotrema hydrium, a new species of Parmeliaceae in southeastern Brazil. Acta Bot. Bras. 2013, 27, 810-814. [CrossRef]

61. Banfield, J.F.; Barker, W.W.; Welch, S.A.; Taunton, A. Biological impact on mineral dissolution: Application of the lichen model to understanding mineral weathering in the rhizosphere. In Proceedings of the National Academy of Sciences, Irvine, CA, USA, 8-9 November 1998.

62. Musulla, S.; Kumari Y, B.; Madala, M.; Rao, S.; Naresh, V.V. Alternative total synthesis of (+)-aspicilin. Synth. Commun. 2018, 48, 1657-1662. [CrossRef]

63. Basile, A.; Rigano, D.; Loppi, S.; Di Santi, A.; Nebbioso, A.; Sorbo, S.; Conte, B.; Paoli, L.; De Ruberto, F.; Molinari, A.M.; et al. Antiproliferative, Antibacterial and Antifungal Activity of the Lichen Xanthoria parietina and Its Secondary Metabolite Parietin. Int. J. Mol. Sci. 2015, 16, 7861-7875. [CrossRef] [PubMed]

64. Ranković, B.; Kosanić, M. Lichens as a Potential Source of Bioactive Secondary Metabolites. In Lichen Secondary Metabolites; Ranković, B., Ed.; Springer: Cham, Switzerland, 2015; pp. 1-26.

65. Furmanek, Ł.; Czarnota, P.; Seaward, M.R.D. Antifungal activity of lichen compounds against dermatophytes: A review. J. Appl. Microbiol. 2019, 127, 308-325. [CrossRef] [PubMed]

66. Shukla, V.; Joshi, G.P.; Rawat, M.S.M. Lichens as a potential natural source of bioactive compounds: A review. Phytochem. Rev. 2010, 9, 303-314. [CrossRef] 
67. Goga, M.; Elečko, J.; Marcinčinová, M.; Ručová, D.; Bačkorová, M.; Bačkor, M. Lichen Metabolites: An Overview of Some Secondary Metabolites and Their Biological Potential. In Co-Evolution of Secondary Metabolites; Springer: Cham, Switzerland, 2018; pp. 1-36.

68. Araújo, A.A.S.; de Melo, M.G.D.; Rabelo, T.K.; Nunes, P.S.; Santos, S.L.; Serafini, M.R.; Santos, M.R.V.; Quintans-Júnior, L.J.; Gelain, D.P. Review of the biological properties and toxicity of usnic acid. Nat. Prod. Res. 2015, 29, 2167-2180. [CrossRef]

69. Bhattacharyya, S.; Deep, P.R.; Singh, S.; Nayak, B. Lichen Secondary Metabolites and Its Biological Activity. Am. J. PharmTech Res. 2016, 6, 29-44.

70. Le Pogam, P.; Boustie, J. Xanthones of Lichen Source: A 2016 Update. Molecules 2016, 21, 294. [CrossRef]

71. Gauslaa, Y.; McEvoy, M. Seasonal changes in solar radiation drive acclimation of the sun-screening compound parietin in the lichen Xanthoria parietina. Basic Appl. Ecol. 2005, 6, 75-82. [CrossRef]

(C) 2020 by the authors. Licensee MDPI, Basel, Switzerland. This article is an open access article distributed under the terms and conditions of the Creative Commons Attribution (CC BY) license (http://creativecommons.org/licenses/by/4.0/). 